\title{
Research on the Peacekeeping English Vocabulary Teaching Based on the Frame Semantics
}

\author{
Lan Yao \\ China Peacekeeping Police Training Center \\ Chinese People's Police University \\ Lang Fang, Hebei, China \\ Yaolan800110@163.com
}

\begin{abstract}
Frame Semantics has been widely used in all aspects of foreign language teaching. Through the experiments conducted in the training course of China Peacekeeping Police Training Center, it proves that the Frame Semantics can effectively improve the learning efficiency. Therefore, the trainers need to constantly update their teaching concepts, optimize their teaching models, and especially improve the teaching methods based on Frame Semantics in order to enhance the peacekeeping English vocabulary teaching.
\end{abstract}

Keywords-Frame Semantics; peacekeeping English; vocabulary teaching; teaching methods

\section{INTRODUCTION}

China's participation in United Nations peacekeeping operations became more and more proactive in recent years. On the September 28th, 2015, Chinese President Xi Jinping attended the seventieth session of the UN General Assembly in the United Nations Headquarters in New York and promised that China would provide 8000 standby peacekeeping forces. To strengthen the contribution for the United Nations peacekeeping operations is the solemn commitment that made by China for world peace. When United Nations Peacekeeping Police (UNPOL) officers work in various host countries, they often face complex political contexts, terrible natural environments and hard living conditions. English is not only their main working language but also a useful tool in their daily life. However, the teaching methodologies of current English training conducted in China Peacekeeping Police Training Center (CPPTC) are not so scientific. Many trainees feel short of the peacekeeping English vocabularies when they work in the United Nations peacekeeping missions. In addition, about $80 \%$ of the courses ongoing in the CPPTC are in English. That is to say, to master the peacekeeping English vocabulary is the precondition of learning peacekeeping English. The vocabulary teaching benefits greatly from the rise of cognitive linguistics, for example, the cognitive approach, archetype and metaphor theory have been widely utilized in English teaching and research in recent years [1]. Frame semantics is one of the important branches of the cognitive linguistics, which can also provide crucial guidance for the peacekeeping English vocabulary teaching both theoretically and practically.

Sponsored by the Education Reform Project of Hebei Province "Research on the Frame Semantics on Peacekeeping English Vocabulary Teaching" (No.2017GJJG251) and the Major Project of National Social Science Fund "Research on the Strategic Choice of China's Participation of the UN Peacekeeping Operations” (No.16ZDA094).

\section{BRIEF INTRODUCTION TO PEACEKEEPING ENGLISH TEACHING}

\section{A. The Basic Concept of Peacekeeping English}

Broadly speaking, peacekeeping English refers to the organic sum of the English vocabularies, sentence patterns and writing styles which are frequently used in United Nations peacekeeping missions. In other word, peacekeeping English is the special professional English used for United Nations peacekeeping operations. The trainees not only need to study the basic English language skills, cross-cultural knowledge, international policing skills and host countries backgrounds, but also need to be familiar with the international laws and politics and some of the other interdisciplinary knowledge. Due to the broad fields involved in peacekeeping English vocabulary, there is a large amount of peacekeeping English vocabulary.

\section{B. The Main Features of Peacekeeping English}

1) Practicality: The aim of peacekeeping English teaching is to serve for the requirements of the UNPOL's work and life in the United Nations Missions. The peacekeeping personnel were recruited from different countries, no matter what they speak in their homeland; they must use English as their official language in the UN missions. English is the foundation for the accomplishment of their tasks. Without English, it is difficult for them to communicate with both their international colleagues and the host country residents. Therefore, practicality is the most important feature of peacekeeping English.

2) Specialization: Peacekeeping English is the main working language frequently used by UNPOLs in UN missions so its content was very specialized. The scope of use of the peacekeeping English covers the fields of police, administration of justice and all the fields related with UN peacekeeping operations. However, these kinds of vocabularies are rarely used in common English learning.

Extensiveness: The extensiveness of peacekeeping English is mainly reflected in its context. According to the requirement of UN pre-deployment training, UNPOL should not only be familiar with the peacekeeping policing skills but also understand all of the background knowledge of UN 
peacekeeping operations such as the UN system, the Security Council mandate, human rights, gender issues, different legal systems, etc. Therefore, peacekeeping English covers a wide range of branches of learning.

\section{The Status Quo of Peacekeeping English Teaching}

China peacekeeping police training started from June 2000 when China deployed the first police contingent to the United Nations Mission in East Timor. Up till June 2019, CPPTC has already assumed 42 peacekeeping police training courses and nearly 3000 trainees received their training here. In the initial period of training, the peacekeeping English teaching adopted the test mode in order to help the trainees who have already possessed the basic English skills to pass the UN selection test successfully. The training course usually lasts for two to three months' time. Then, the content of peacekeeping English teaching has also adjusted with the new development of the requirements of UN selection test in recent years, for example, the Core Pre-deployment Training Module (CPTM) and Specific Training Module(STM) have been added and updated gradually. All of the training materials are developed by the United Nations Integrated Training Unit and the trainers use English to illustrate those training modules throughout the whole training.

Peacekeeping English is a practical and professional language and the vocabulary is one of the most important link of peacekeeping English teaching. It is not helpful for the memory and use of the peacekeeping English vocabularies if the trainers adopt the traditional methods. Although most of the trainees possess solid English skills, some of them have poor learning outcomes. On the one hand, they are the lack of special and professional peacekeeping vocabulary, on the other hand, they are still influenced by traditional learning methods. The special features and pragmatic value of peacekeeping English decide the requirements for the vocabulary to be mastered by the trainees, both on the "quantity" and the "quality", are very high. Although both the trainers and the trainees have already invested a large amount of time and energy on the vocabularies in the current peacekeeping English teaching, the learning effect is still far from satisfaction. Therefore, the trainers in CPPTC need to constantly improve the teaching methods, optimize the teaching modes and explore the new teaching methods in order to improve the learning effect of the trainees.

\section{FRAME SEMANTICS AND ITS APPLICATION IN FOREIGN LANGUAGE TEACHING}

Frame Semantics is an important theoretical framework of Cognitive Linguistics which studies the conceptual structure of human beings in terms of semantic frames. Frame Semantics was formally brought forward by the American linguist Fillmore Charles in 1982.

\section{A. The Central Ideas of Frame Semantics}

When Fillmore first used the frame notion, he defined it as "any system of linguistic choices - the easiest cases being collections of words, but also including choices of grammatical rules or linguistics categories - that can get associated with prototypical instances of scenes" (Fiillmore,1975: 124) According to this definition, a frame was an array of linguistic options which were associated with the so-called "scene". The basic assumption of frame semantics is that in order to understand the meanings of the words in a language we must first have knowledge of the conceptual structures, or semantic frames, which provide the background and motivation for their existence in the language and for their use in discourse [2] Word meanings are best understood in reference to the conceptual structures which support and motivate them, and any description of word meanings must begin by identifying such underlying conceptual structures.

\section{B. The Application of Frame Semantics in Foreign Language Teaching at Abroad}

In recent decades, with the thriving of Cognitive Linguistics, Frame Semantics began to gain more and more attention from scholars and researchers. Present studies on Frame Semantics have covered the fields ranging from morphology to discourse analysis, translation and language acquisition. However, for the most part, studies on Frame Semantics seem to have focused on lexicography, especially computational lexicography. Fillmore took the verb "risk" as an example to illustrate how to use the frames to discuss the polysemy. He pointed out that when people edited the dictionaries, they can learn from the research results of Frame Semantic. As for vocabulary teaching, according to the literature within our reach, very little research has been done to apply frame semantics to this field and few researchers have conducted systematic research on it.

\section{The Application of Frame Semantics in Foreign Language Teaching in China}

The development of Frame Semantics at abroad soon attracts much interest and attention from many Chinese scholars. However, most efforts in this field are at a superficial level, mainly focusing on the translation of Fillmore's works and the general introduction of the theory. Only a few scholars have taken the initiative to conduct research on the application of this theory. Some scholars have also stressed the significant role of frames can play in vocabulary understanding any have done some research on applying Frame Semantics into English Vocabulary Teaching[3]. The results of these studies are promising and their contributions to English teaching are significant. However; most of these studies are basically taken at theoretical level. Little research, if any, has been done systematically and practically. Compared to the descriptive and theoretical research of Frame Semantics, there is still large room for the development of practical research in foreign language teaching, especially English vocabulary teaching in China.

\section{APPLyING FRAME SEMANTICS TO PEACEKEEPING ENGLISH VOCABULARY TEACHING}

As we stated in the introduction of this thesis, there is inefficiency in the traditional approach to peacekeeping English vocabulary teaching in CPPTC. Despite the fact that much importance has been attached to vocabulary and much effort has been devoted to vocabulary teaching and learning, 
vocabulary still lies ahead in the way as a main impediment to the development of trainees' English skills. Therefore, in order to change the present situation, it is urgent to develop new approaches as replacement of the traditional approach to peacekeeping English vocabulary teaching [4].

\section{A. A Model Design for Peacekeeping English Vocabulary Teaching}

Brow and Payee (1994) used a model for vocabulary teaching, which is composed of five steps: (1) encountering the new words, (2) getting the forms of the new words, (3) learning the meanings of the words, (4) making a memory connection between the forms and meanings; and (5) using the words [5]. Here we will borrow Brown and Payne's five-step model, but we will integrate it with the Frame Semantics theory by introducing frames into analysis of word meanings, and through the introduction of frames, we will rearrange this model into three stages: (1) the prior-framing stage, when we encounter the new words in context and use the context as cognitive information to help to evoke specific frames for further-meaning understating in the later stage; (2)the framing stage, when word meanings are learned and consolidated through frame construction and description; ie. The process of framing and (3) the post framing stage, when we enhance students' mastery of the new words through refraining, i.e., try to apply the target words to different contexts.

\section{B. Peacekeeping English Vocabulary Teaching Experiment Research}

In order to elaborate on our model proposed above, we have implemented the vocabulary teaching method based on framework semantics in peacekeeping training. The author chose two parallel classes of the same number from the 42 UNPOL Training Course as the research subject and conducted a three-month teaching experiment. One is the control class; the other is the test class. The control class adopted the traditional vocabulary teaching methods, such as reading, interpretation, etymology, affix and giving typical examples etc. While the test class adopted the vocabulary teaching method based on Frame Semantics [6]

The author tested the two classes before and after the experiment. The test before the experiment aims to understand current peacekeeping English language proficiency of the two classes and to specifically set the teaching aim and organize the class. After three-month training, the author test the two classes which intends to know the latest situation of the peacekeeping English language proficiency and to get the scientific and accurate statistics of the change of the English language proficiency of the two classes so as to see whether the Frame Semantics has the positive influence on the peacekeeping English vocabulary learning. In addition, the author designed the questionnaire in order to know the feedback from the trainees.

\section{Experimental Data Collection and Analysis}

The author designed the pre-experimental test paper and after- experimental test paper. There were 34 trainees from the test group and 30 trainees from the control group participated in the tests. In order to study whether there is an obvious difference of the peacekeeping vocabulary learning results between the test group and the control group, the author analyzed the score data of the pre-experiment

1) Analysis of the score data of the pre-experiment

TABLE I. GROUP STATISTICS

\begin{tabular}{|c|c|c|c|c|c|}
\hline & Group & $\boldsymbol{N}$ & Mean & $\begin{array}{c}\text { Std. } \\
\text { Deviation }\end{array}$ & Std. Error Mean \\
\hline \multirow{2}{*}{$\begin{array}{c}\text { Pre- } \\
\text { test }\end{array}$} & Experimental & 54 & 78.41 & 9.141 & 1.244 \\
\cline { 2 - 6 } & Control Class & 50 & 79.54 & 9.455 & 1.337 \\
\hline
\end{tabular}

TABLE II. INDEPENDENT SAMPLES TEST

\begin{tabular}{|c|c|c|c|c|c|c|c|c|c|c|}
\hline & \multicolumn{2}{|c|}{$\begin{array}{c}\text { Levene's Test for } \\
\text { Equality of Variances }\end{array}$} & \multicolumn{7}{|c|}{ t-test for Equality of Means } \\
\hline & & \multirow[t]{2}{*}{$F$} & \multirow[t]{2}{*}{ Sig } & \multirow[t]{2}{*}{$t$} & \multirow[t]{2}{*}{$d f$} & \multirow[t]{2}{*}{ Sig.(2-tailed) } & \multirow{2}{*}{$\begin{array}{c}\text { Mean } \\
\text { Difference }\end{array}$} & \multirow{2}{*}{$\begin{array}{l}\text { Std. Error } \\
\text { Difference }\end{array}$} & \multicolumn{2}{|c|}{$\begin{array}{c}\text { 95\% Confidence Interval } \\
\text { of the Difference }\end{array}$} \\
\hline & & & & & & & & & Lower & Upper \\
\hline \multirow{2}{*}{$\begin{array}{l}\text { Pre- } \\
\text { test }\end{array}$} & $\begin{array}{l}\text { Equal variances } \\
\text { assumed }\end{array}$ & 0.127 & 0.722 & -0.621 & 102 & 0.536 & -1.133 & 1.824 & -4.750 & 2.485 \\
\hline & $\begin{array}{c}\text { Equal variances } \\
\text { not assumed }\end{array}$ & & & -0.620 & 100.75 & 0.537 & -1.133 & 1.826 & -4.756 & 2.490 \\
\hline
\end{tabular}

TABLE I and TABLE II are the analysis of the preexperiment score data of the test group and control group. The average score of the test group is 78.41 and the standard deviation is 9.141 . The average score of the control group is 79.54 and the standard deviation is 9.455. TABLE II is the variance analysis. From the table, we can see that the $F$ value is 0.127 and its significant level $\mathrm{P}$ value is 0.722 , greater than 0.05 , which indicates that there were no significant differences of the scores of the trainees from different classes.
2) Analysis of the score data of the after-experiment

TABLE III. GROUP STATISTICS

\begin{tabular}{|c|c|c|c|c|c|}
\hline & Group & $\boldsymbol{N}$ & Mean & $\begin{array}{c}\text { Std. } \\
\text { Deviation }\end{array}$ & Std. Error Mean \\
\hline \multirow{2}{*}{$\begin{array}{c}\text { Pre- } \\
\text { test }\end{array}$} & Experimental & 54 & 85.63 & 7.752 & 1.055 \\
\cline { 2 - 6 } & Control Class & 50 & 81.2 & 8.748 & 1.237 \\
\hline
\end{tabular}


TABLE IV. INDEPENDENT SAMPLES TEST

\begin{tabular}{|c|c|c|c|c|c|c|c|c|c|c|}
\hline & & \multicolumn{2}{|c|}{$\begin{array}{c}\text { Levene's Test for } \\
\text { Equality of Variances }\end{array}$} & \multicolumn{7}{|c|}{ t-test for Equality of Means } \\
\hline & & \multirow[t]{2}{*}{$\boldsymbol{F}$} & \multirow{2}{*}{ Sig } & \multirow[t]{2}{*}{$t$} & \multirow[t]{2}{*}{$d f$} & \multirow{2}{*}{$\begin{array}{l}\text { Sig.(2- } \\
\text { tailed) }\end{array}$} & \multirow{2}{*}{$\begin{array}{c}\text { Mean } \\
\text { Difference }\end{array}$} & \multirow{2}{*}{$\begin{array}{l}\text { Std. Error } \\
\text { Difference }\end{array}$} & \multicolumn{2}{|c|}{$\begin{array}{c}\text { 95\% Confidence Interval } \\
\text { of the Difference }\end{array}$} \\
\hline & & & & & & & & & Lower & Upper \\
\hline \multirow{2}{*}{$\begin{array}{c}\text { Post- } \\
\text { test }\end{array}$} & Equal variances assumed & 0.659 & 0.419 & 2.737 & 102 & 0.007 & 4.43 & 1.618 & 1.220 & 7.639 \\
\hline & $\begin{array}{c}\text { Equal variances not } \\
\text { assumed }\end{array}$ & & & 2.725 & 98.172 & 0.008 & 4.43 & 1.626 & 1.203 & 7.656 \\
\hline
\end{tabular}

TABLE III and TABLE IV are the analysis of the afterexperiment score data of the test group and control group. The average score of the test group is 85.63. The average score of the control group is 81.2. The average score after the experiment in the test class is nearly five percentage points higher than the average after the control class. TABLE IV is the variance analysis. From the TABLE IV we can see that the $\mathrm{F}$ value is 0.659 and its significant level $\mathrm{P}$ value is 0.419 , greater than 0.05 , which indicates that there were significant differences of the scores of the trainees from different classes after the experiment. Thus it proves that the teaching method based on Frame Semantics can effectively improve the trainees’ peacekeeping English vocabulary level.

In order to make a comparison of the conclusions clearer, this thesis also compares the results of the test and control classes with themselves before and after the experiment. The comparison results can once again prove whether Frame Semantics really helps trainees' vocabulary learning and improves their English scores. The author firstly compares the pre-experiment with the after-experiment score of the test class. The detailed analysis data is as follows:

3) Comparative analysis of the pre-experiment with the after-experiment scores of the test class

TABLE V. Paired SAMPles Statistics

\begin{tabular}{|c|l|c|c|c|c|}
\hline \multicolumn{2}{|c|}{} & $N$ & Mean & $\begin{array}{c}\text { Std. } \\
\text { Deviation }\end{array}$ & $\begin{array}{c}\text { Std. Error } \\
\text { Mean }\end{array}$ \\
\hline \multirow{3}{*}{ Pair1 } & Pre-test & 54 & 78.41 & 9.141 & 1.244 \\
\cline { 2 - 6 } & Post-test & 54 & 85.63 & 7.752 & 1.055 \\
\hline
\end{tabular}

TABLE VI. PAIRED SAMPLEs TeST

\begin{tabular}{|c|c|c|c|c|c|c|c|c|c|}
\hline & & \multicolumn{5}{|c|}{ Paired Differences } & \multirow{3}{*}{$t$} & \multirow{3}{*}{$d f$} & \multirow{3}{*}{ Sig.(2-tailed) } \\
\hline & & \multirow{2}{*}{ Mean } & \multirow{2}{*}{$\begin{array}{c}\text { Std. } \\
\text { Deviation }\end{array}$} & \multirow{2}{*}{$\begin{array}{l}\text { Std. Error } \\
\text { Mean }\end{array}$} & \multicolumn{2}{|c|}{$\begin{array}{c}\text { 95\% Confidence Interval of the } \\
\text { Difference }\end{array}$} & & & \\
\hline & & & & & Lower & Upper & & & \\
\hline Pair1 & Pre-test-post-test & -7.222 & 3.511 & 0.478 & -8.181 & -6.264 & -15.116 & 53 & 0.000 \\
\hline
\end{tabular}

From the data of the TABLE V and TABLE VI we can see that there are significant differences between the preexperiment and the after-experiment scores of the test class. The average pre-experiment score of the control group is 78.41 . After three-month training experiment, the average score after the experiment in the test class is 85.63 , which is nearly seven percentage points higher than the average score of preexperiment. The improvement is quite obvious. From the above TABLE V we can see that the trainees in the test class have a significant value of 0.000 in the comparison between the "preexperiment score" and the "post-experiment score". It is less than 0.01 , which reaches a significant level at the 0.01 level. It indicates that there are significant differences of between the pre-experiment and the after-experiment scores of the test class.
Thus it proves that the teaching method based on Frame Semantics can effectively improve the trainees' peacekeeping English vocabulary level.

4) Comparative analysis of the pre-experiment with the after-experiment scores of the control class

TABLE VII. Paired SAmples Statistics

\begin{tabular}{|c|l|c|c|c|c|}
\hline \multicolumn{2}{|c|}{} & $N$ & Mean & $\begin{array}{c}\text { Std. } \\
\text { Deviation }\end{array}$ & Std. Error Mean \\
\hline \multirow{2}{*}{ Pair1 } & Pre-test & 50 & 79.54 & 9.455 & 1.337 \\
\cline { 2 - 6 } & Post-test & 50 & 81.2 & 8.748 & 1.237 \\
\hline
\end{tabular}

TABLE VIII. PAIRED SAmples Test

\begin{tabular}{|c|c|c|c|c|c|c|c|c|c|}
\hline & & \multicolumn{5}{|c|}{ Paired Differences } & \multirow{3}{*}{$t$} & \multirow{3}{*}{$d f$} & \multirow{3}{*}{ Sig.(2-tailed) } \\
\hline & & \multirow{2}{*}{ Mean } & \multirow{2}{*}{$\begin{array}{c}\text { Std. } \\
\text { Deviation }\end{array}$} & \multirow{2}{*}{$\begin{array}{c}\text { Std. } \\
\text { Error } \\
\text { Mean }\end{array}$} & \multicolumn{2}{|c|}{ 95\% Confidence Interval of the Difference } & & & \\
\hline & & & & & Lower & Upper & & & \\
\hline Pair1 & Pre-test-post-test & -1.66 & 1.912 & 0.27 & -2.204 & -1.116 & -6.138 & 49 & 0 \\
\hline
\end{tabular}


From the data of the TABLE VII and TABLE VIII we can see that the average pre-experiment score of the control class is 79.54. And the average score after the experiment in the control class is 81.20 , which is less that one percentage point higher than the average score of pre-experiment. Although the trainees of the control class have made some progress, it is not obvious compared with the test class. From the above TABLE VIII we can see that the trainees in the test class have a significant value of 0.000 in the comparison between the "preexperiment score" and the "post-experiment score". It is less than 0.01 , which reaches a significant level at the 0.01 level. It indicates that there are significant differences between the preexperiment and the after-experiment scores of the test class. Thus it proves that the traditional teaching method can also improve the trainees' peacekeeping English vocabulary level.

\section{CONCLUSION}

Frame Semantics has shown important theoretical guidance and application value in the field of foreign language teaching. Trainers of CPPTC can explore the peacekeeping English vocabulary teaching method with the help of the concept of "Frame". Through the experiment, the author finds that the application of Frame Semantics can effectively improve the trainees' learning efficiency of the peacekeeping English vocabulary. However, the research of the applying Frame
Semantics in peacekeeping English vocabulary teaching is still not very mature. The trainers need to build the new Frame Semantics teaching model through a large number of the teaching cases and to test the effectiveness of the teaching model through long term teaching.

\section{REFERENCES}

[1] Evans, Vyvyan and Green, Melanie, Cognitive linguistics: An introduction. Edinburgh: Edinburgh University Press, 2006, pp. 171-182.

[2] Baker, Collin F., Fillmore, Charles J., and Lowe, John B. The Berkeley FrameNet project. In Proceedings of the COLING- ACL, 1998, Montreal, Canada.

[3] Qian Deming and Zhou Qingfang, "Revelation of frame semantics on English vocabulary teaching” Jiang Su: Journal of Suzhou Institute of Education, 2nd ed., vol. 22. pp.68-73, 2005.

[4] Tang Ying, “Applying Frame Semantics to College English Vocabulary Teaching” [D], 2013, unpublished.

[5] Brown C and Payne, M.E, "Five essential steps of process in vocabulary learning”, 1994, Paper presented at the TESOL Convention Baltimore Md.

[6] Deng Hua, "Experimental Research on College English Writing Teaching”, Jiang Xi: Journal of Jiangxi Vocational and Technical College of Electricity, Vol.31 No.3, 2018, pp.28-30. (In Chinese) 